\title{
Template-Free Electrochemical Preparation of Hexagonal CuSn Prism-Structural Electrode for Lithium-Ion Batteries
}

\author{
Xiaona Pan, ${ }^{1}$ Haiyan Zhang, ${ }^{2}$ Xiaoyu Wen, ${ }^{1}$ Jinqiu Zhang, ${ }^{1}$ Maozhong An, \\ and Peixia Yang (iD ${ }^{1}$ \\ ${ }^{1}$ MIIT Key Laboratory of Critical Materials Technology for New Energy Conversion and Storage, School of Chemistry and \\ Chemical Engineering, Harbin Institute of Technology, No. 92 West Dazhi Street, Harbin 150001, China \\ ${ }^{2}$ College of Life Science, Henan University, Kaifeng 475004, China
}

Correspondence should be addressed to Peixia Yang; yangpeixia@hit.edu.cn

Received 3 May 2018; Revised 30 July 2018; Accepted 5 August 2018; Published 8 October 2018

Academic Editor: Linqin $\mathrm{Mu}$

Copyright (c) 2018 Xiaona Pan et al. This is an open access article distributed under the Creative Commons Attribution License, which permits unrestricted use, distribution, and reproduction in any medium, provided the original work is properly cited.

\begin{abstract}
A hexagonal prism CuSn alloy was prepared at room temperature from 1-ethyl-3-methylimidazolium dicyanamide ([Emim][DCA]) by the direct template-free electrodeposition method with different concentrations of $\mathrm{Cu}(\mathrm{I})$ and $\mathrm{Sn}$ (II) at a low current density of $0.04 \mathrm{~A} \mathrm{dm}^{-2}$. Moreover, the electrodeposition time was also investigated, and the results indicated that the composition of the CuSn alloy became complex and the structure turned unstable with expanding time. The cycling performance of the hexagonal prism-structural CuSn electrode was investigated, with the first discharge capacity of $345 \mathrm{mAh} \mathrm{g}^{-1}$ and a discharge capacity of about $210 \mathrm{mAh} \mathrm{g}^{-1}$ after 10 cycles.
\end{abstract}

\section{Introduction}

Tin is well investigated as an anode material for lithium-ion batteries (LIB) owing to its high storage capacity (theoretical capacity is $\left.993.3 \mathrm{mAh} \mathrm{g}^{-1}\right)[1,2]$. However, during the charge and discharge process, $\mathrm{Li}$ intercalation and deintercalation causes the Sn electrode to undergo massive volume expansion and contraction due to the generation of $\mathrm{Li}_{\mathrm{x}} \mathrm{Sn}$ alloy, which causes mechanical disintegration that leads to a poor cycle performance [3].

To stabilize the morphology of Sn anode materials, many efforts have been made to minimize the mechanical stress in the electrodes that cause the volume change. The results of investigations indicate that the Sn alloy [4-6] can effectively buffer the volume expansion during the charge/discharge process, thus improving structural stability and anode material cycle performance. $\mathrm{Cu}-\mathrm{Sn}$ alloys are studied as anode materials for LIB due to their advantages, such as a stabilized structure, lower cost, environmental friendliness, and especially excellent conductivity. Moreover, the CuSn alloy often is the most commonly formed using template methods by chemical vapor deposition [7], sol-gel processing [8], and electrodeposition [9]. As known to all, electrodeposition is widely used by industrial production and lab experiments due to its simple process, easy operation, uniform sedimentation, and so on. Furthermore, ionic liquids usually have a wide electrochemical window and show ideal electrolytes for electrodeposition application; it can especially obtain different microstructural platings in ILs $[10,11]$. Sun et al. have reported a method that allowed electrochemical growth of metal alloys from ILs, obtaining a nanotube alloy [11] and a nanowire alloy [12].

Herein, we utilized the direct template-free electrodeposition method to synthesize CuSn from 1-ethyl-3-methylimidazolium dicyanamide ([Emim][DCA]). A prism structure of $\mathrm{Cu}-\mathrm{Sn}$ was obtained, and it could provide a high surface area and a large number of active sites for charge transfer. Hence, this structure can alleviate the large volume change that induces mechanical disintegration during the charge/ discharge process. Furthermore, the cycle performance of LIB, which has a hexagonal $\mathrm{Cu}-\mathrm{Sn}$ prism as the anode, was also investigated. 


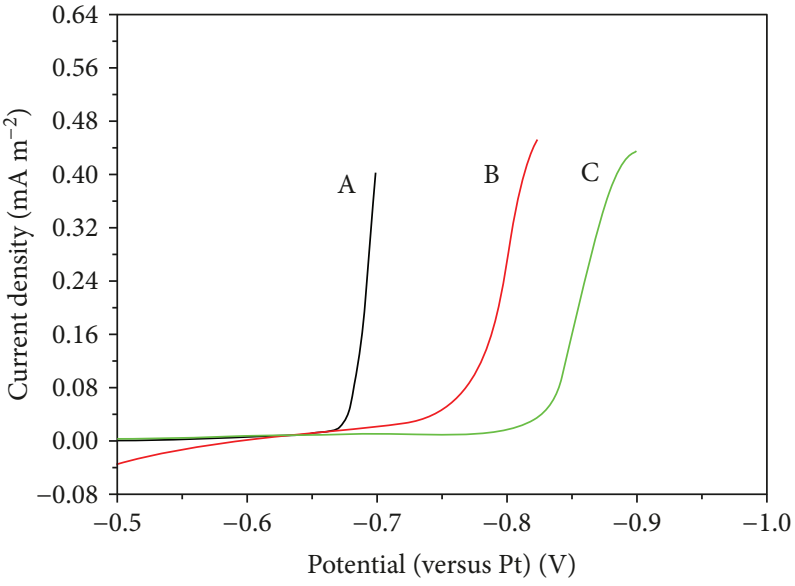

(a)

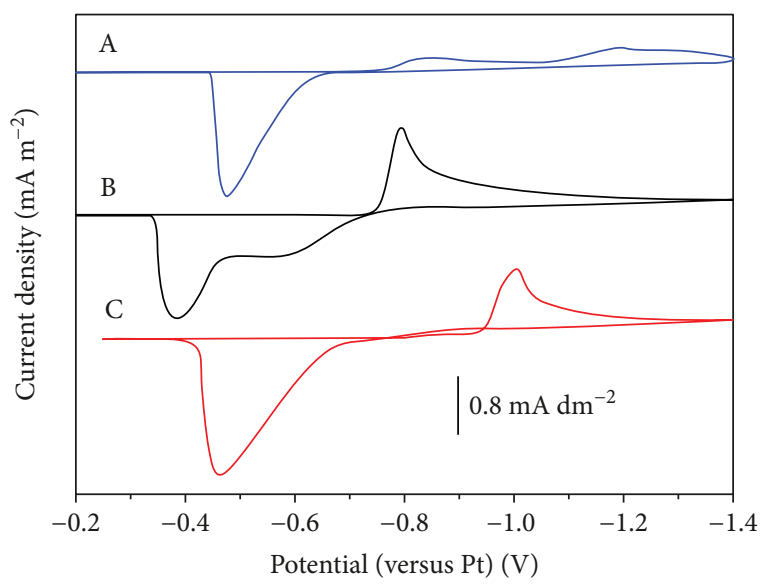

(b)

Figure 1: (a) Cathodic polarization curves of a Pt electrode for solutions of [Emim][DCA] containing: (A) $0.05 \mathrm{M}$ Sn(II), (B) 0.1 M $\mathrm{Cu}(\mathrm{I})+0.05 \mathrm{M} \mathrm{Sn}(\mathrm{II})$, and (C) $0.1 \mathrm{M} \mathrm{Cu}(\mathrm{I})$ at a scan rate of $0.01 \mathrm{~V} \mathrm{~s}^{-1}$. (b) Cyclic voltammogram curves of a Pt electrode for solutions of [Emim][DCA] containing: (A) $0.1 \mathrm{M} \mathrm{Cu}(\mathrm{I})$, (B) $0.05 \mathrm{M} \mathrm{Sn}(\mathrm{II})$, and (C) $0.1 \mathrm{M} \mathrm{Cu}(\mathrm{I})+0.05 \mathrm{M} \mathrm{Sn}$ (II) at a scan rate of $0.05 \mathrm{~V} \mathrm{~s}{ }^{-1}$. The scanning direction of $\mathrm{CV}$ is shown as an arrow in (b).

\section{Experimental}

The deposition electrolytes were prepared by the dissolution of various amounts of $\mathrm{CuCl}$ and $\mathrm{SnCl}_{2} \cdot 2 \mathrm{H}_{2} \mathrm{O}$ ( $\geq 99.99 \%$, Sigma-Aldrich) into [Emim][DCA] in the glove box. The electrochemical experiments were tested in a three-electrode system using a CHI660E electrochemical workstation. A Pt wire $(\Phi 0.5 \mathrm{~mm})$ was used as the counter electrode and a Pt foil immersed in deposition electrolytes was used as the reference. A Pt wire $(\Phi 0.38 \mathrm{~mm})$ was used as the working electrode for $\mathrm{CV}$ measurements, and a $\mathrm{Cu}$ foil $(2 \mathrm{~cm} \times 2 \mathrm{~cm})$ was used as a substrate for electrodeposition.

The cell with the CuSn alloy as anode and lithium metal as cathode was assembled on a glovebox filled with argon $\left(\mathrm{H}_{2} \mathrm{O}, \mathrm{O}_{2}<0.5 \mathrm{ppm}\right)$. The Celgard 2400 was the separator and the electrolyte was $1 \mathrm{M} \mathrm{LiPF}_{6} \mathrm{PC} / \mathrm{DEC}(\mathrm{v} / \mathrm{v}=1: 1)$. The cycling performance of the cell was cycled at a current density of $\mathrm{C} / 10$ at room temperature.

\section{Results and Discussion}

Figure 1(a) displays the cathodic polarization curves of [Emim][DCA] containing $0.05 \mathrm{M} \mathrm{Sn}(\mathrm{II}), 0.1 \mathrm{M} \mathrm{Cu}(\mathrm{I})+$ $0.05 \mathrm{M} \mathrm{Sn}(\mathrm{II})$, and $0.1 \mathrm{M} \mathrm{Cu}(\mathrm{I})$. The curves have a rising current attributed to the electrodeposition of $\mathrm{Sn}(-0.66 \mathrm{~V}$ versus $\mathrm{Pt}), \mathrm{Cu}-\mathrm{Sn}(-0.75 \mathrm{~V}$ versus $\mathrm{Pt})$, and $\mathrm{Cu}(-0.82 \mathrm{~V}$ versus $\mathrm{Pt}$ ). This indicates that the addition of $\mathrm{Sn}(\mathrm{II})$ is beneficial to $\mathrm{Cu}$ electrodeposition with a $\mathrm{Cu}$ and $\mathrm{Sn}$ synergy codeposition process. Figure 1(b) shows cyclic voltammogram curves and it reveals that the $\mathrm{Sn}(\mathrm{II}) / \mathrm{Sn}$ couple [13] occur at a potential far more positive than the $\mathrm{Cu}(\mathrm{I}) / \mathrm{Cu}$ couple [14]. Intriguingly, the two redox processes merge together and the potentials are shifted toward each other when the solution contains $\mathrm{Cu}(\mathrm{I})$ and $\mathrm{Sn}$ (II), suggesting that there is a strong interaction between $\mathrm{Cu}$ and $\mathrm{Sn}$. In the $\mathrm{CV}$, the reduction peak at $-1.0 \mathrm{~V}$ and stripping peak at $-0.47 \mathrm{~V}$ (vs. Pt) can correspond to the codeposition and strip of the $\mathrm{Cu}-\mathrm{Sn}$ alloy, which is evidenced by the XRD spectra displayed in Figure 2. The results of the CV agree with the cathodic polarization.

Figure 2 shows SEM images for a typical $\mathrm{Cu}$ substrate electrodeposited with $\mathrm{Cu}-\mathrm{Sn}$ in different concentrations of $\mathrm{Cu}(\mathrm{I})$ and $\mathrm{Sn}(\mathrm{II})$ at a current density of $0.04 \mathrm{~A} \mathrm{~cm}^{-2}$ for $1 \mathrm{~h}$. Dendrite-like structures are obtained in the electrolyte with $0.04 \mathrm{M} \mathrm{Cu}(\mathrm{I})$ and $0.02 \mathrm{M} \mathrm{Sn}(\mathrm{II})$ (Figure 2(a)); with the increase in concentration, the $\mathrm{Cu}$ substrate is covered by a large quantity of outward growing $\mathrm{Cu}-\mathrm{Sn}$ hexagonal prisms with diameters ranging from around $5 \mu \mathrm{m}$ to $10 \mu \mathrm{m}$ (Figure 2(b)). As the concentration continues to increase, uniform $\mathrm{Cu}-\mathrm{Sn}$ hexagonal prisms are formed and the length of the prisms is about $20 \mu \mathrm{m}$ (Figures 2(c) and 2(d)). The different sizes of the prisms may result from the initial nucleation time which is related to the concentration of $\mathrm{Cu}(\mathrm{I})$ and $\mathrm{Sn}(\mathrm{II})$. Higher concentration results from nucleation more easily produced and earlier nucleation formed larger prisms because there is a longer time period for the prism to grow [10].

The crystal structure of the as-deposited $\mathrm{Cu}$-Sn prism at different deposition times was tested and shown in Figure 3. As shown in SEM images (Figures 3(a)-3(c)), the diameter of the $\mathrm{Cu}-\mathrm{Sn}$ prism increases with the increase in deposition time. The tubular hexagonal $\mathrm{Cu}-\mathrm{Sn}$ with an inner diameter of around $10-20 \mu \mathrm{m}$ could be observed, but its structure is nonuniform, and its parts have some drawbacks (Figure 3(c)).

The diffraction patterns can be indexed to those of the $\mathrm{Cu}_{10} \mathrm{Sn}_{3}, \mathrm{Cu}_{3} \mathrm{Sn}$, and $\mathrm{Cu}$ dominant peaks that resulted from the substrate (Figure 3(d)). As can be seen in Figure 3(d), there are other peaks $\left(\mathrm{Cu}_{5.6} \mathrm{Sn}\right.$ and $\left.\mathrm{Cu}_{4} \mathrm{Sn}\right)$ when the electrodeposition time is extended to $1.5 \mathrm{~h}$. Moreover, the structure of $\mathrm{CuSn}$ is inhomogeneous and unsteady (Figure 3(c)). Furthermore, the ratio of the $\mathrm{Cu}-\mathrm{Sn}$ alloy is examined with 


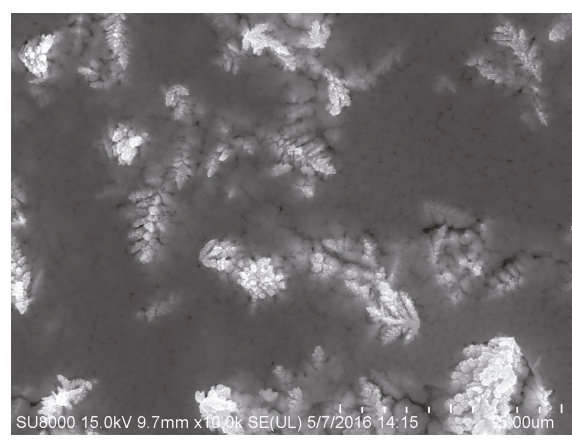

(a)

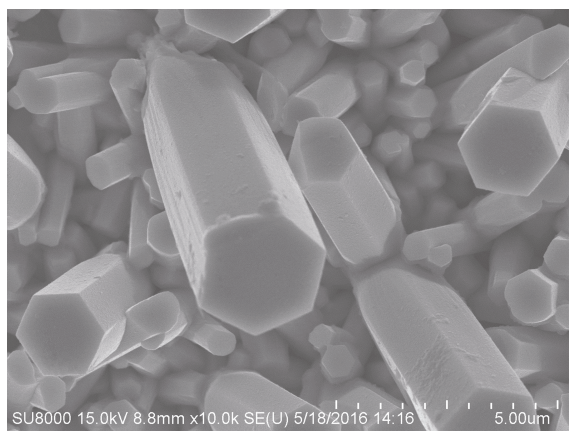

(c)

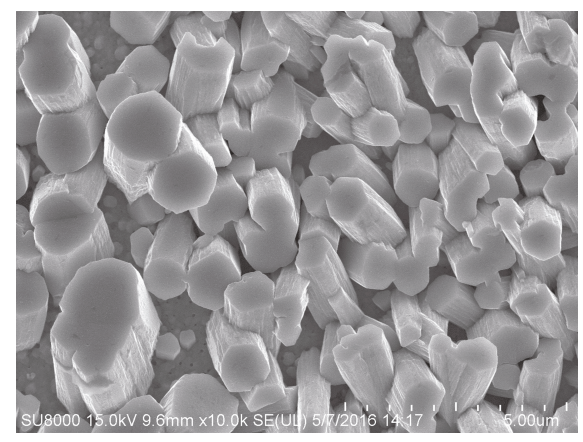

(b)

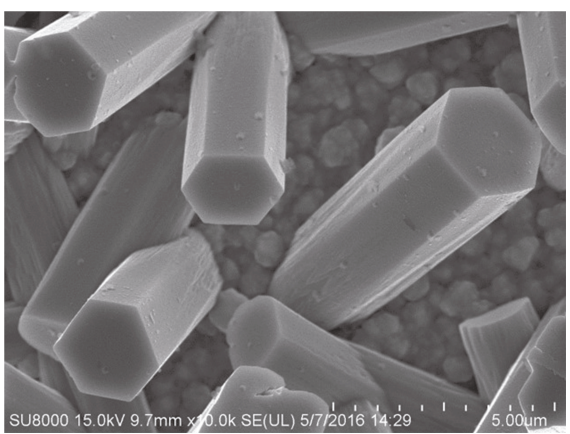

(d)

Figure 2: SEM images for a typical Cu substrate electrodeposited with $\mathrm{Cu}-\mathrm{Sn}$ in different concentrations of $\mathrm{Cu}(\mathrm{I})$ and $\mathrm{Sn}(\mathrm{II})$ at a current density of $0.04 \mathrm{~A} \mathrm{~cm}^{-2}$ for $1 \mathrm{~h}$ : (a) $0.04 \mathrm{M} \mathrm{Cu}(\mathrm{I})+0.02 \mathrm{M} \mathrm{Sn}$ (II), (b) $0.06 \mathrm{M} \mathrm{Cu}$ (I) $+0.03 \mathrm{M} \mathrm{Sn}$ (II), (c) $0.08 \mathrm{M} \mathrm{Cu}$ (I) $+0.04 \mathrm{M} \mathrm{Sn}$ (II), and (d) $0.1 \mathrm{M} \mathrm{Cu}(\mathrm{I})+0.05 \mathrm{M} \mathrm{Sn}(\mathrm{II})$.

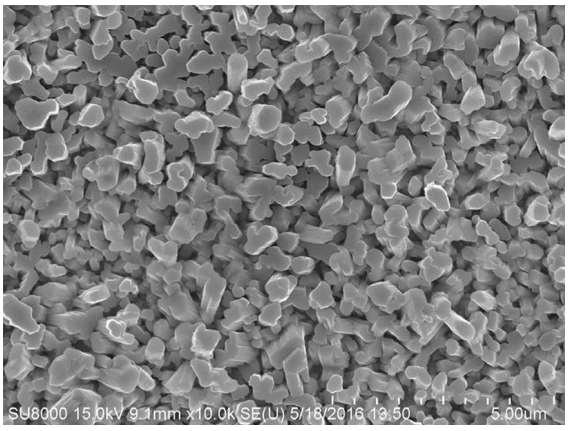

(a)

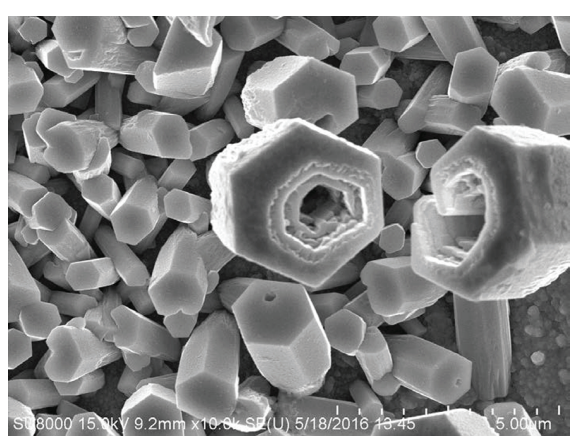

(c)

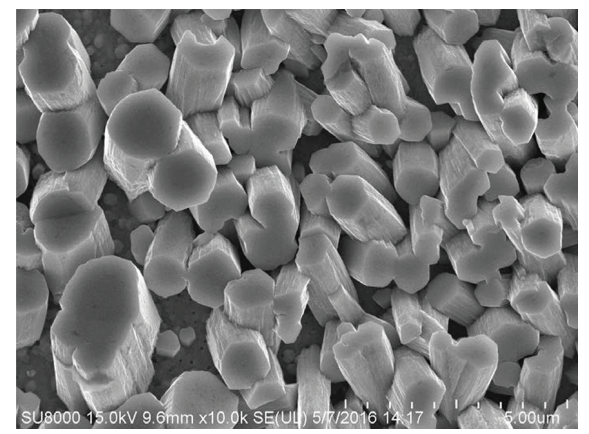

(b)

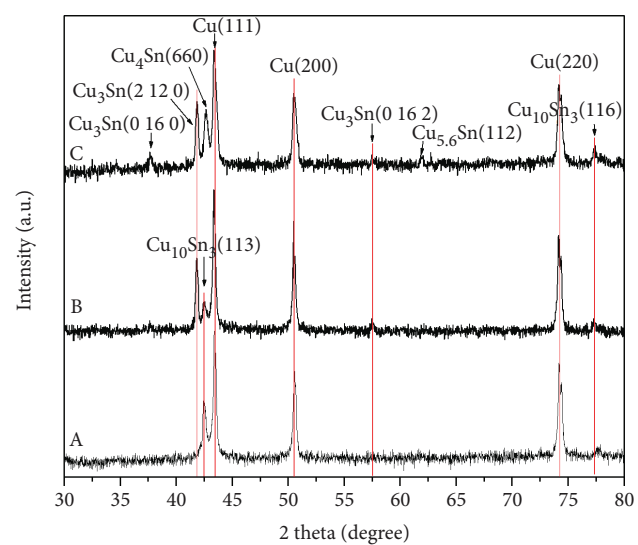

(d)

Figure 3: SEM images (a, b, and c) and XRD patterns (d) of the as-deposited Cu-Sn in electrolyte with $0.06 \mathrm{~mol} \mathrm{~L}^{-1} \mathrm{CuCl}_{\text {and }} 0.03 \mathrm{~mol} \mathrm{~L}$ $\mathrm{SnCl}_{2}$ at a current density of $0.04 \mathrm{~A} \mathrm{~cm}^{-2}$ for different deposition times: (A) $0.5 \mathrm{~h}$, (B) $1 \mathrm{~h}$, and (C) $1.5 \mathrm{~h}$. 


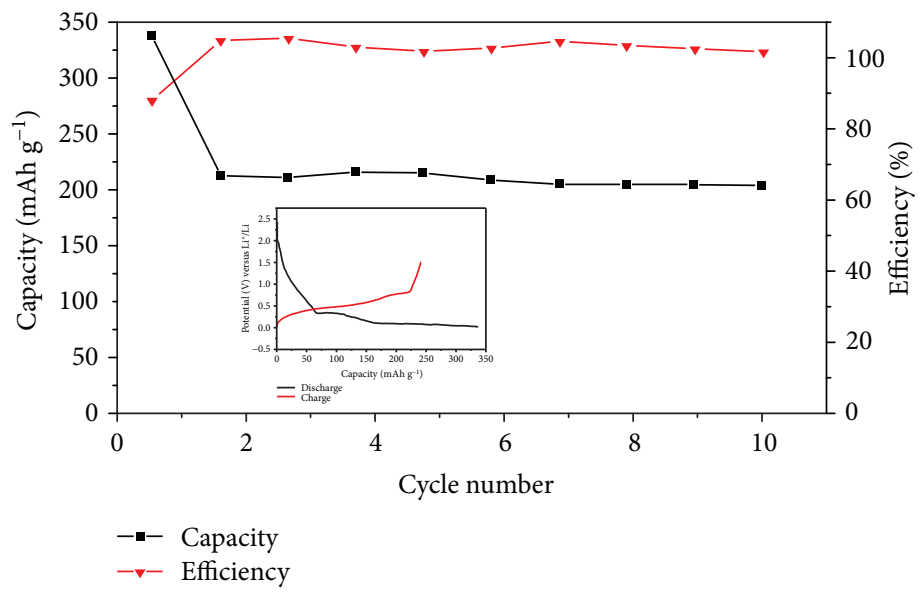

FIgURE 4: Charge-discharge performance and coulombic efficiency of a Cu-Sn cell at a current density of C/10 at room temperature.

energy dispersive X-ray analysis (EDS), and the results reveal only $\mathrm{Cu}$ and $\mathrm{Sn}$ elements in the substrate with a 3.5:1 ratio of $\mathrm{Cu} / \mathrm{Sn}$, corresponding to the stoichiometry of $\mathrm{Cu}_{10} \mathrm{Sn}_{3}$. The formation of hexagonal $\mathrm{Cu}-\mathrm{Sn}$ is unique and the growth mechanism is not very clear. Both the natural environment and the property of $\mathrm{Cu}$ and $\mathrm{Sn}$ metals provided by the ionic liquid may have an important role in hexagonal prism growth.

Figure 4 displays the cycling performance and coulombic efficiency of the $\mathrm{Cu}-\mathrm{Sn}$ cell at a current density of $\mathrm{C} / 10$ at room temperature. The first discharge platform of the $\mathrm{Cu}-\mathrm{Sn}$ cell is about $0.35 \mathrm{~V}$ and the first charge platform is $0.5 \mathrm{~V}$ (inset in Figure 4). The initial charge and discharge capacities are about $250 \mathrm{mAh} \mathrm{g}^{-1}$ and $345 \mathrm{mAh} \mathrm{g}^{-1}$, respectively. The initial cycle irreversible loss in capacities and lower coulombic efficiency can be seen in Figure 4. It may be attributed to the SEI film formed in the electrode surface and this is an irreversible process [15-17]. After 10 cycles, the discharge capacity stays at $210 \mathrm{mAh} \mathrm{g}^{-1}$ and the coulombic efficiency is about $100 \%$. The capacity is lower than the theoretical capacity of $\mathrm{Sn}$ due to the $\mathrm{Cu}-\mathrm{Sn}$ prism still undergoing volume expansion, but the hexagonal prism with $\mathrm{Cu}-\mathrm{Sn}$ as the anode of LIB has an acceptable cycling performance $[1,18,19]$. Decreasing the size of the $\mathrm{Cu}-\mathrm{Sn}$ prism or changing the condition during the preparation of nanostructural $\mathrm{Cu}-\mathrm{Sn}$ probably could improve its capacity and cycle performance $[20,21]$.

\section{Summary}

The electrocrystallization of the hexagonal $\mathrm{Cu}-\mathrm{Sn}$ prism, which is difficult to achieve in an aqueous solution, was obtained for the first time in a [Emim] [DCA] ionic liquid at room temperature. Using the hexagonal $\mathrm{Cu}-\mathrm{Sn}$ prism as the anode for LIB shows that the first discharge capacity is $345 \mathrm{mAh} \mathrm{g}^{-1}$ and the discharge capacity stays at $210 \mathrm{mAh} \mathrm{g}^{-1}$ after 10 cycles. The cell performance should be improved further; therefore, an in-depth study of this approach will provide a more precise control of the prism size for a synthesis of the nanostructure of the CuSn alloy for LIB.

\section{Data Availability}

(1) The cathodic polarization data used to support the findings of this study are included within the article. (2) The cyclic voltammogram data used to support the findings of this study are included within the article. (3) The XRD data used to support the findings of this study are included within the article. (4) The SEM images used to support the findings of this study are included within the article.

\section{Conflicts of Interest}

The authors declare that they have no conflicts of interest.

\section{Acknowledgments}

This project was supported by the National Natural Science Foundation of China (Grant no. 21276057).

\section{References}

[1] J. W. Park, J. Y. Eom, and H. S. Kwon, "Charge-discharge characteristics of a layered-structure electroplated $\mathrm{Cu} / \mathrm{Sn}$ anode for Li-ion batteries," Electrochimica Acta, vol. 55, no. 5, pp. 1825-1828, 2010.

[2] X. Chen, J. Guo, K. Gerasopoulos et al., "3D tin anodes prepared by electrodeposition on a virus scaffold," Journal of Power Sources, vol. 211, pp. 129-132, 2012.

[3] J. Hassoun, S. Panero, P. Simon, P. L. Taberna, and B. Scrosati, "High-rate, long-life $\mathrm{Ni}-\mathrm{Sn}$ nanostructured electrodes for lithium-ion batteries," Advanced Materials, vol. 19, no. 12, pp. 1632-1635, 2007.

[4] H. Y. Lee, S. W. Jang, S. M. Lee, S. J. Lee, and H. K. Baik, "Lithium storage properties of nanocrystalline $\mathrm{Ni}_{3} \mathrm{Sn}_{4}$ alloys prepared by mechanical alloying," Journal of Power Sources, vol. 112, no. 1, pp. 8-12, 2002.

[5] X. Chen, Q. Ru, Z. Wang, X. Hou, and S. Hu, "Ternary SnSb-Co alloy particles embedded in reduced graphene oxide as lithium ion battery anodes," Materials Letters, vol. 191, pp. 218-221, 2017. 
[6] S. D. Beattie and J. R. Dahn, "Single bath, pulsed electrodeposition of copper-tin alloy negative electrodes for lithium-ion batteries," Journal of the Electrochemical Society, vol. 150, no. 7, article A894, 2003.

[7] Y. Wang and K. Wu, "As a whole: crystalline zinc aluminate nanotube array-nanonet," Journal of the American Chemical Society, vol. 127, no. 27, pp. 9686-9687, 2005.

[8] Y. Yu, H. Qiu, X. Wu et al., "Synthesis and characterization of silica nanotubes with radially oriented mesopores," Advanced Functional Materials, vol. 18, no. 4, pp. 541-550, 2008.

[9] L. Comai, J. C. Zomerdijk, H. Beckmann, S. Zhou, A. Admon, and R. Tjian, "Reconstitution of transcription factor SL1: exclusive binding of TBP by SL1 or TFIID subunits," Science, vol. 266, no. 5193, pp. 1966-1972, 1994.

[10] Y. T. Hsieh, T. I. Leong, C. C. Huang, C. S. Yeh, and I. W. Sun, "Direct template-free electrochemical growth of hexagonal CuSn tubes from an ionic liquid," Chemical Communications, vol. 46, no. 3, pp. 484-486, 2010.

[11] M. Armand, F. Endres, D. R. MacFarlane, H. Ohno, and B. Scrosati, "Ionic-liquid materials for the electrochemical challenges of the future," Nature Materials, vol. 8, no. 8, pp. 621-629, 2009.

[12] Y. T. Hsieh and I. W. Sun, "Electrochemical growth of hierarchical CuSn nanobrushes from an ionic liquid," Electrochemistry Communications, vol. 13, no. 12, pp. 15101513, 2011.

[13] M. J. Deng, T. I. Leong, I. W. Sun, P. Y. Chen, J. K. Chang, and W. T. Tsai, "Fabrication of porous tin by template-free electrodeposition of tin nanowires from an ionic liquid," Electrochemical and Solid-State Letters, vol. 11, no. 11, article D85, 2008.

[14] T. I. Leong, I. W. Sun, M. J. Deng, C. M. Wu, and P. Y. Chen, "Electrochemical study of copper in the 1-ethyl-3-methylimidazolium dicyanamide room temperature ionic liquid," Journal of the Electrochemical Society, vol. 155, no. 4, article F55, 2008

[15] M. T. Lawder, P. W. C. Northrop, and V. R. Subramanian, "Model-based SEI layer growth and capacity fade analysis for EV and PHEV batteries and drive cycles," Journal of the Electrochemical Society, vol. 161, no. 14, pp. A2099A2108, 2014.

[16] H. Ekström and G. Lindbergh, "A model for predicting capacity fade due to SEI formation in a commercial graphite/ $\mathrm{LiFePO}_{4}$ cell," Journal of the Electrochemical Society, vol. 162, no. 6, pp. A1003-A1007, 2015.

[17] M. Sina, R. Thorpe, S. Rangan et al., "Investigation of SEI layer formation in conversion iron fluoride cathodes by combined STEM/EELS and XPS," Journal of Physical Chemistry C, vol. 119, no. 18, pp. 9762-9773, 2015.

[18] M. Winter and J. O. Besenhard, "Electrochemical lithiation of tin and tin-based intermetallics and composites," Electrochimica Acta, vol. 45, no. 1-2, pp. 31-50, 1999.

[19] Y. Xia, T. Sakai, T. Fujieda, M. Wada, and H. Yoshinaga, "Flake $\mathrm{Cu}-\mathrm{Sn}$ alloys as negative electrode materials for rechargeable lithium batteries," Journal of the Electrochemical Society, vol. 148, no. 5, article A471, 2001.
[20] M. G. Kim, S. Sim, and J. Cho, "Novel core-shell Sn-Cu anodes for lithium rechargeable batteries prepared by a redoxtransmetalation reaction," Advanced Materials, vol. 22, no. 45 , pp. 5154-5158, 2010.

[21] D. G. Kim, H. Kim, H. J. Sohn, and T. Kang, "Nanosized $\mathrm{Sn}-\mathrm{Cu}-\mathrm{B}$ alloy anode prepared by chemical reduction for secondary lithium batteries," Journal of Power Sources, vol. 104, no. 2, pp. 221-225, 2002. 


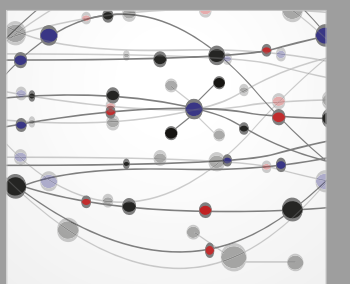

The Scientific World Journal
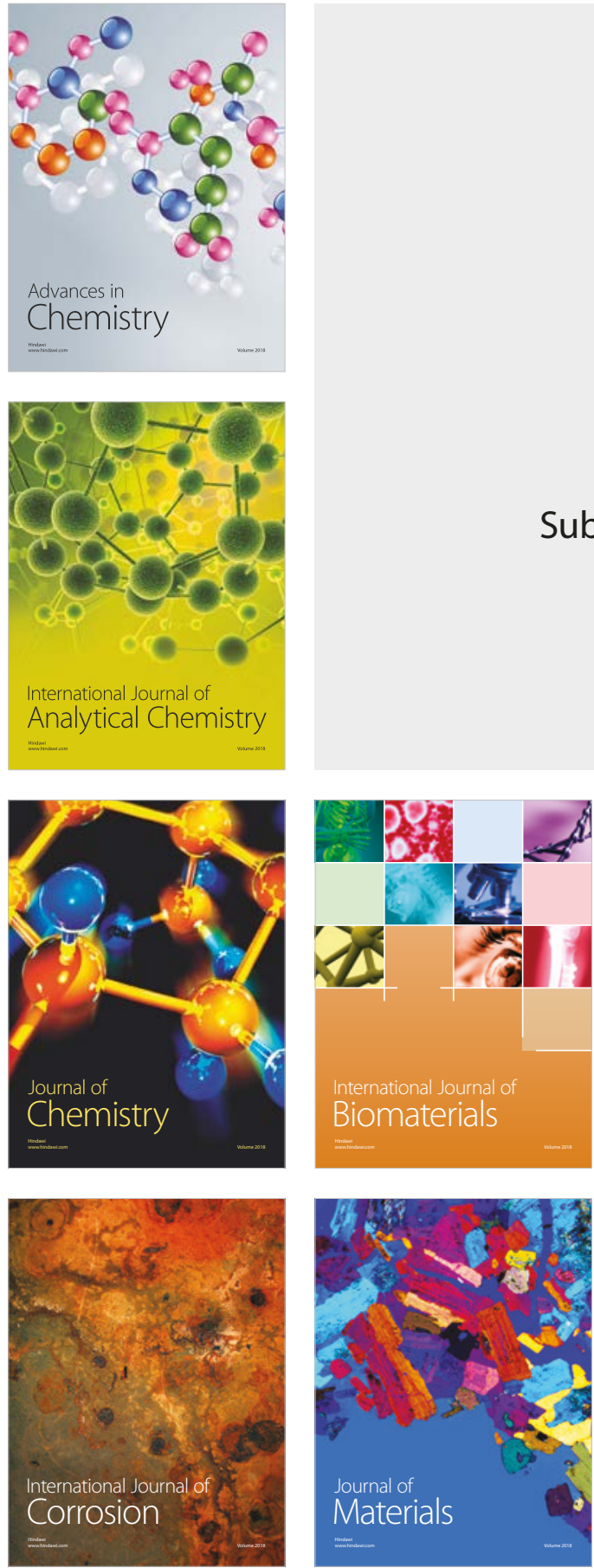

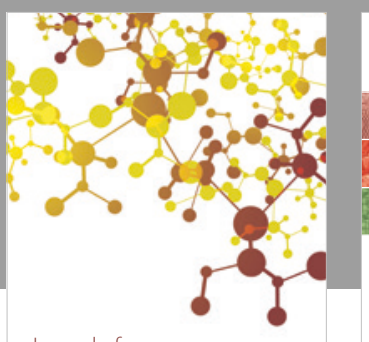

Journal of

Applied Chemistry
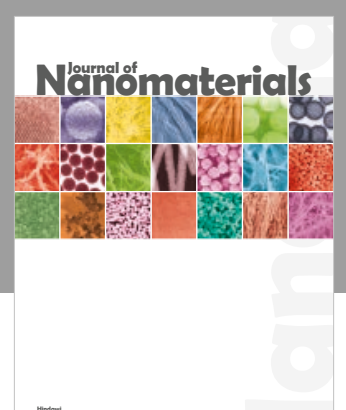

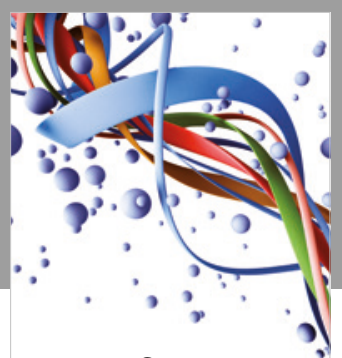

Scientifica

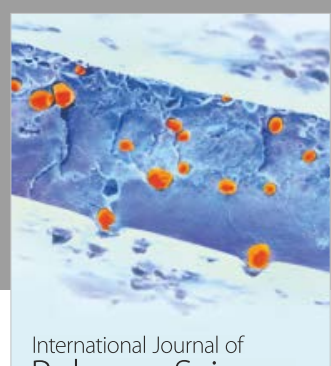

Polymer Science

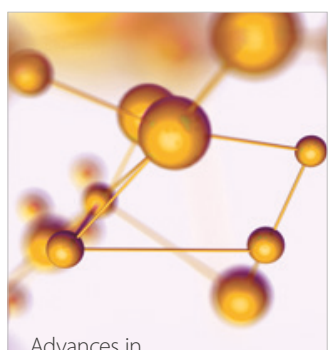

Physical Chemistry
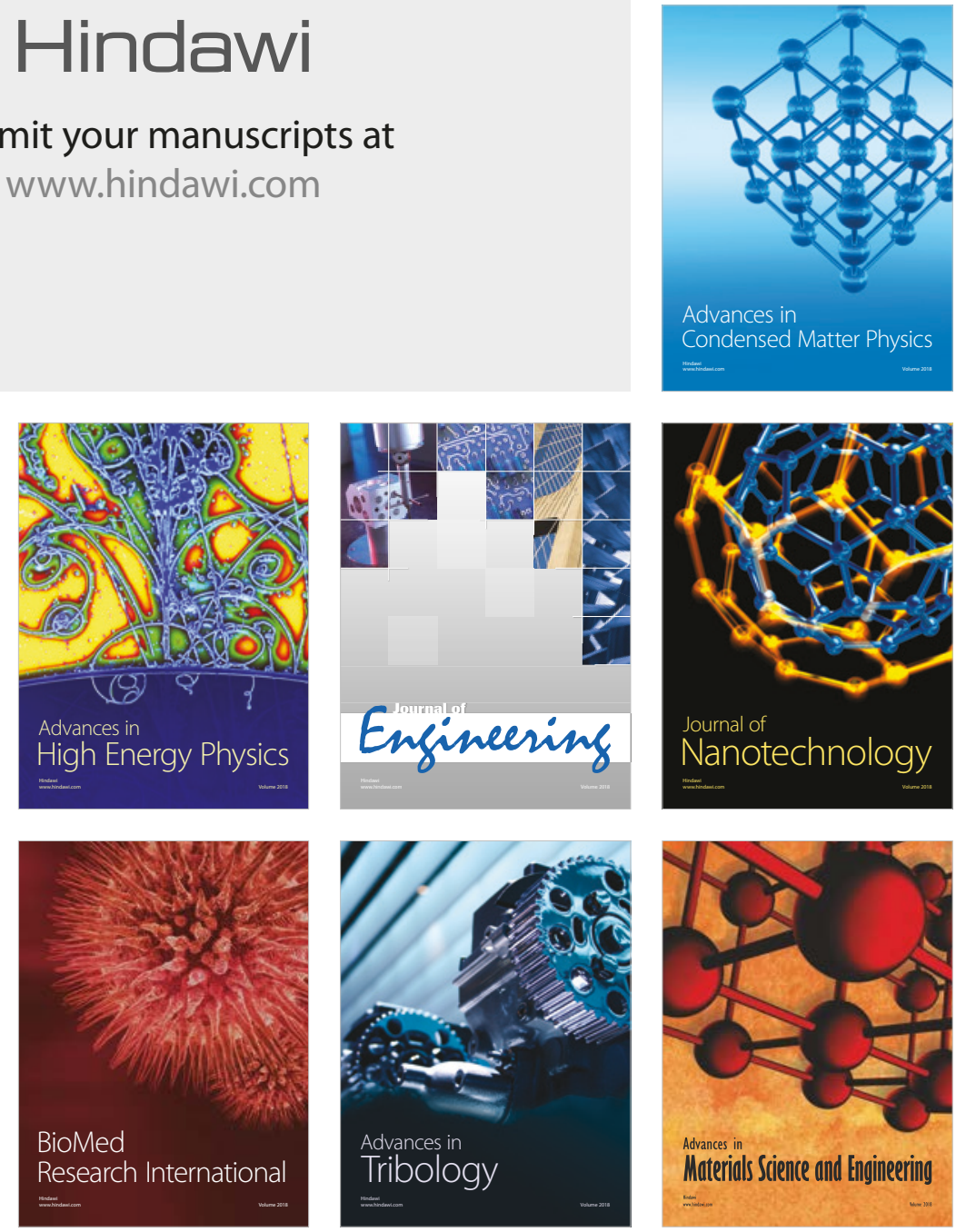